\title{
Splenic infarction as a rare cause of abdominal pain in older adults: A case report
}

\author{
Yaşlılarda nadir bir karın ağrısı nedeni splenik infarkt: Olgu sunumu
}

Ayşe Daylan (1) Sevnaz Şahin (D) Selahattin Fehmi Akçiçek (i)

Ege University, Division of Geriatrics, Department of Internal Medicine, Bornova, Izmir, Turkey

\begin{abstract}
Spontaneous splenic infarction has been rarely reported within aged population. The diagnosis of the condition is based on clinical findings and splenic imaging. In recent years, ultrasonography and computed tomographic scan have gained in popularity for the diagnosis of splenic infarction. Most reported cases are focal infarctions, and treatment is mostly conservative. We described the case of a 82-year-old female with cured breast cancer, paroxysmal atrial fibrillation, hypertension who had left upper quadrant pain within 15 days. Physical examination on admission revealed a palpable splenomegaly. Abdominal computed tomography scan showed many subcapsular infarct zones of the spleen measuring $16 \mathrm{~cm}$ in length and $4.5 \mathrm{~cm}$ conglomerate lymphadenopathies within periportal region. Doppler ultrasound revealed wedge-shaped heterogeneous hypoechoic avascular areas and lymphadenopathies. After laboratory tests, the underlying cause was found as marginal zone lymphoma. The patient was treated with conservative management and chemotherapy was planned for specific cause. Splenic infarction must be kept in mind for older patients with underlying comorbidities presenting with acute left upper quadrant pain.
\end{abstract}

Keywords: Older adult, splenic infarction, abdominal pain.

\section{ÖZ}

Spontan dalak infarktı, yaşlı yetişkinlerde nadir görülen karın ağrısı nedenlerinden biridir. Tanı; klinik bulgular ve görüntüleme yöntemleri ile konur. Geçmiş yıllarda ultrasonografi ve bilgisayarlı tomografinin splenik infarkt tanısındaki yeri önem kazanmıştır. Raporlanmış çoğu dalak infarktı fokaldir ve konservatif tedavi edilmektedir. 82 yaşında kadın hasta, 15 gün önce başlayan karın ağrısı nedeni ile başvurdu ve özgeçmişinde meme kanseri, paroksismal atriyal fibrilasyon ve hipertansiyon olduğu öğrenildi. Fizik muayenede; dalak kot altında palpe edilmekteydi. Bilgisayarlı tomografide; $16 \mathrm{~cm}$ uzunlukta ölçülen dalağın içinde subkapsüler infarkt alanları ve periportal alanda $4,5 \mathrm{~cm}$ çaplı konglomere lenfadenopati saptandı. Doppler ultrasonografide kama şeklinde infarkt alanları ve heterojen hipoekoik avasküler alanlar olduğu görüldü. Laboratuvar tetkikleri sonrasında altta yatan nedenin marjinal zon lenfoma olduğu saptandı. Hastaya konservatif tedavi verildi ve hematolojik maligniteye yönelik kemoterapi planı yapıldı. Komorbiditeleri olan yaş/ı yetişkinlerde, akut başlangıçlı sol üst kadran ağrısıyla karşılaşıldığında dalak infarktı akılda tutulması gereken bir durumdur.

Anahtar Sözcükler: Yaşlı, splenik infarkt, karın ağrısı.

\section{INTRODUCTION}

Abdominal pain is a common complaint among older adults. The differential diagnosis of acute abdominal pain includes many medical conditions such as acute cholecystitis, acute pancreatitis, peptic ulcer perforation, mesenteric ischemia, intestinal obstruction and aortic aneurysm. Misdiagnosis of acute abdominal pain is more common within aged population, and results with higher mortality (1).

\footnotetext{
Corresponding author: Ayşe Daylan

Ege University, Division of Geriatrics, Department of Internal

Medicine, Bornova, Izmir, Turkey

E-mail: ayse.daylan@ege.edu.tr
} 
Splenic infarction is a rare medical condition of older patients which cause acute abdominal pain. The most common causes of splenic infarction are hematologic diseases, bacterial endocarditis, cardioembolic events, sickle cell anemia and procoagulant conditions. Atypical presentation is not rare, but majority of the patients have fever, nausea, vomiting and left upper quadrant pain radiating to back and left shoulder. As in many other diseases peritoneal inflammation signs and fever are usually absent in older adults (2).

\section{CASE PRESENTATION}

An 82-year-old female patient admitted to the hospital with left upper quadrant abdominal pain radiating to shoulder for the last 15 days. Comorbidities of the patient were breast cancer and paroxysmal atrial fibrillation. She was considered cured after mastectomy and chemotherapy. Additionally, she was using irregular warfarin for paroxysmal atrial fibrillation. She was examined in another hospital for abdominal pain and computerized tomography (CT) was performed. CT revealed splenomegaly of $16 \mathrm{~cm}$ in length and heterogeneity of spleen. She was diagnosed as spleen infarction and hospitalized, and treatment for cardioembolic spleen infarction was started. Additionally, ceftriaxone was given for a possibility of infective endocarditis because of her fever. However transthoracic echocardiogram showed no vegetation, and the pain could not be controlled during follow-up, and fever was never documented again. With these atypical findings, diagnosis of cardioembolic spleen infarction and infective endocarditis were reconsidered and the patient was transferred to tertiary hospital for further investigation and management.

The physical examination revealed body temperature of $36^{\circ} \mathrm{C}$. Blood pressure was $130 /$ $60 \mathrm{mmHg}$, heart rate was $103 / \mathrm{min}$ and rhythmic. There was no extra murmur. Crepitation was heard on left lower lob of lung area. The abdomen was tender, left upper quadrant of abdomen was defensive with no rebound. Dull tone was heard in Traube region and spleen was palpable. Left costovertebral angle was tender. No peripheral lymph nodes were palpated, and other examination findings were normal.

Laboratory tests performed resulted as, leukocytes: $808010^{\wedge} 3 / \mu \mathrm{L}$, neutrophil: 5760 $10^{\wedge} 3 / \mu \mathrm{L}$, hemoglobin: $11,2 \mathrm{~g} / \mathrm{dL}$, platelet: $17200010^{\wedge} 3$ / $\mu \mathrm{L}$, sodium: $139 \mathrm{mEq} / \mathrm{L}$, potassium: $4 \mathrm{mEq}$ / L, clor: $101 \mathrm{mEq} / \mathrm{L}$, urea: 26 $\mathrm{mg} / \mathrm{dL}$, creatinine: $0,73 \mathrm{mg} / \mathrm{dL}$, AST: $52 \mathrm{U} / \mathrm{L}$, ALT: 15 U / L, GGT: 211 U / L, ALP: 117 U / L, CRP: $153 \mathrm{mg} / \mathrm{L}$, LDH: $1045 \mathrm{U} / \mathrm{L}$ and erythrocyte sedimentation rate: $30 \mathrm{~mm} / \mathrm{h}$. Peripheric blood cultures were negative.

We discontinued antibiotic treatment because there was no evidence of infective endocarditis. The patient had no fever for over 10 days, no murmur was heard in cardiac auscultation regions. And blood cultures were negative. As the patient had paroxysmal atrial fibrillation, enoxaparin sodium of 6000 IU per day was ordered for routine use. Abdominal pain did not resolve with $1 \mathrm{gr}$ of intravenous paracetamol four times a day so we started intravenous tramadol of $50 \mathrm{mg}$ twice a day which was prominently enough for pain palliation. No oxygen therapy was needed. During follow-up she had acute severe abdominal pain despite use of tramadol. Another CT was performed for differential diagnosis of a possible splenic rupture. CT was reported as splenomegaly with subcapsular wedge shaped infarct zones and patent splenic artery and left sided peritoneal thickening. There were no signs of splenic rupture. The pain dissolved with intravenous tramadol of $100 \mathrm{mg}$ use for 3 days and peroral form was prescribed to use when necessary.

Infectious diseases tests for Epstein-Barr virus, cytomegalovirus, salmonella, brucella, leishmania, Echinococcus granulosis and hepatitis viruses were performed, and resulted negative. No Plasmodium was detected in thick blood smear. Cirrhosis and heart failure were excluded with the help of clinical findings. Portal system doppler ultrasonography (USG) was performed for portal blood flow investigation and documented hypoechoic conglomerated lymph nodes of $4.5 \mathrm{~cm}$ in diameter in periportal region, heterogeneity of spleen with hypoechoic regions and a possible focal infarct zone or decreased perfusion area of $4 \times 4 \mathrm{~cm}$.

Peripheral blood smear test was performed to find the etiology of splenomegaly. Dysplastic neutrophils hypo segmentation, toxic granulation, ring nucleus, Pelger-Huet anomaly and hairy cell projections of lymphocytes were detected. With the help of documented splenomegaly and lymphadenopathies in imaging methods and peripheral blood smear findings the diagnosis changed to splenic infarction caused by a hematologic malignity. 


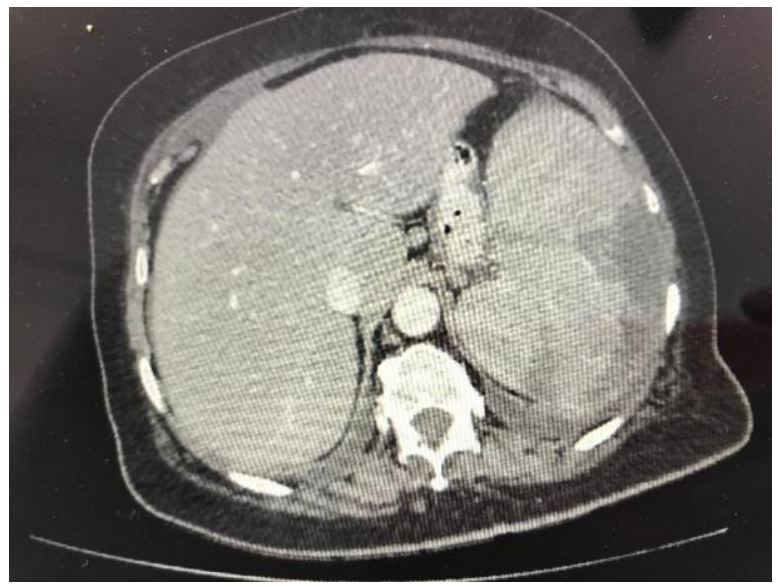

Figure-1. Splenic infarction on axial section of contrast enhanced computed tomography of abdomen.

The patient was consulted to general surgery department for splenectomy or excisional lymph node biopsy for definite diagnosis, however operation was found highly risky for the patient with joint decision. Instead of splenectomy bone, marrow biopsy was preferred because it was less invasive and safer for the patient. The definitive diagnosis has been pathologically documented by bone marrow biopsy as marginal zone lymphoma.

\section{DISCUSSION}

Acute abdominal pain is a common cause of hospital admissions among older adults. Unlike young adults it is difficult to diagnose correctly in advanced aged population. Difficulties for taking reliable medical history, atypical disease presentations, delayed symptoms, late admission to hospital and less evident clinical findings may lead to misdiagnosis more often (3).

Spleen infarction is a rare condition in older adults which presents with acute abdominal pain, fever, nausea, vomiting, leukocytosis and splenomegaly (2). In older patients, symptoms may be less evident, and fever and peritoneal irritation signs may be dimmer.

The causes of splenic infarction may include splenomegaly of hematologic diseases, septic emboli, cardioembolic events, sickle cell anemia, prothrombotic conditions such as Antiphospholipid syndrome.

In a retrospective study, the most common causes of splenic infarctions were found to be hematologic and prothrombotic events (4). Another study of Antopolsky et al revealed that $71 \%$ of patients with spleen infarction were found to have another underlying disease. In the same study, the most common cause for known thrombosis risk factor was found as atrial fibrillation in $21 \%$ of patients. Essential hypertension and diabetes mellitus were present in $31 \%$ and $23 \%$ of the patients, respectively (5). Our patient had a combination of hematological infiltrative malignancy and cardioembolic risk factors.

Splenic infarction must be kept in mind for patients with acute abdominal pain who have splenomegaly and procoagulant conditions and cardioembolic risk factors. However, not all patients present with abdominal pain. A study showed only half of the patients had pain in the upper left quadrant, and $36 \%$ of all had tenderness in the left abdomen (2).

Diagnosis of splenic infarction is easily made with Doppler USG and CT imaging along with clinical findings (6). In the case we presented, the diagnosis was finalized with the presence of wedge shaped areas that were lack of blood flow.

Treatment is usually conservative and aimed at pain palliation. In the presence of fever, splenic abscess must be kept in mind, and antibiotic therapy should be planned at the point where infectious causes are considered (7). It is important to determine the underlying cause of splenic infarction and to treat the main cause so that this condition does not recur. In our case, enoxaparin and treatment with analgesics was continued due to the fact that there was also a history of atrial fibrillation. Cardioembolic causes were considered first, but further examinations were carried out due to incompatibility in clinical and laboratory findings and a preliminary diagnosis of spleen infarction due to hematological malignancy was approached.

Splenectomy is not required in every splenic infarction. Indications for splenectomy include subcapsular hematoma, splenic pseudocyst, abscess and splenic rupture (8). In our patient, the possibility of splenic rupture was also considered because of the development of severe pain with sudden onset but was not detected in imaging methods. Splenectomy may be necessary for a definitive diagnosis when there is a preliminary diagnosis of a malignant disease. In our case, a bone marrow biopsy was preferred because it was more comfortable for the patient, and had low morbidity. Therefore, we did not need splenectomy for further 
investigation. As a result, the patient was diagnosed with marginal zone lymphoma, and the actual treatment plan was revised.

Marginal zone lymphoma is a hematological malignancy that can often cause splenomegaly, and about half of patients are of advanced age (9). Splenic infarction of marginal zone lymphoma is not often, but a case was reported with recurrent infarctions (10). Our case is interesting because it is a marginal zone lymphoma case that presents with acute abdominal pain and is diagnosed with splenic infarction.

\section{CONCLUSION}

Although there are many conditions that can cause abdominal pain in the elderly, splenic infarction is a condition that should be kept in mind, especially in the upper left quadrant and acute abdominal pain. Determining the etiology of splenic infarction is the main predictor of prognosis.

The case report was prepared with patients informed consent.

\section{Conflict of interest}

There is no conflict of interest between the authors.

\section{References}

1. Lyon C, Clark DC. Diagnosis of acute abdominal pain in older patients. Am Fam Physician 2006; 74 (9): 1537-44.

2. Lawrence YR, Pokroy R, Berlowitz D, Aharoni D, Hain D, Breuer GS. Splenic infarction: an update on William Osler's observations. Isr Med Assoc J 2010; 12 (6): 362-5.

3. Spangler R, Van Pham T, Khoujah D, Martinez JP. Abdominal emergencies in the geriatric patient. Int $J$ Emerg Med 2014; 7: 43.

4. Nores M, Phillips EH, Morgenstern L, Hiatt JR. The clinical spectrum of splenic infarction. Am Surg 1998; 64 (2): 182-8.

5. Antopolsky M, Hiller N, Salameh S, Goldshtein B, Stalnikowicz R. Splenic infarction: 10 years of experience. Am J Emerg Med 2009; 27 (3) :262-5.

6. Vancauwenberghe T, Snoeckx A, Vanbeckevoort D, Dymarkowski S, Vanhoenacker FM. Imaging of the spleen: what the clinician needs to know. Singapore Med J 2015; 56 (3): 133-44.

7. Chapman J, Helm TA, Kahwaji Cl. Splenic Infarcts. [Updated 2020 Aug 16]. In: StatPearls [Internet]. Treasure Island $\quad(F L)$ : StatPearls Publishing; 2020 Jan-. Available from: https://www.ncbi.nlm.nih.gov/books/NBK430902/

8. Jaroch MT, Broughan TA, Hermann RE. The natural history of splenic infarction. Surgery 1986; 100 (4): 743-50.

9. Goede V. Marginal zone lymphoma in elderly and geriatric patients. Best Pract Res Clin Haematol 2017; 30 (1-2): 158-65.

10. Tun NT, Mi K, Smith J. Unusual Course of Splenic Marginal Zone Lymphoma. World J Oncol 2013; 4 (4-5): 205-9. 